\title{
Baptists and Bootleggers in the Biodiesel Trade: EU-Biodiesel (Indonesia)
}

\author{
Carolyn Fischer ${ }^{1}$ and Timothy Meyer ${ }^{2 *}$ \\ ${ }^{1}$ Vrije Universeit Amsterdam and University of Ottawa and ${ }^{2}$ Vanderbilt University Law School \\ *Corresponding author. Email: tim.meyer@Law.Vanderbilt.edu
}

(Received 8 January 2020; accepted 8 January 2020)

\begin{abstract}
EU-Biodiesel (Indonesia) is the latest in two lines of cases. On the one hand, the case offers yet another example of the Dispute Settlement Body striking down creative interpretations of antidumping rules by developed countries. Applying the Appellate Body's decision in EU-Biodiesel (Argentina), the panel found that the EU could not use antidumping duties to counteract the effects of Indonesia's export tax on palm oil. On the other hand, the decision is another chapter in the battle over renewable energy markets. Both the EU and Indonesia had intervened in their markets to promote the development of domestic biodiesel industries. The panel's decision prevents the EU from using antidumping duties to preserve market opportunities created by its Renewable Energy Directive for its domestic biodiesel producers. The EU has responded in two ways. First, through regulations that disfavor palm-based biodiesel, but not biodiesel made from from other foodstocks, such as rapeseed oil commonly produced in the EU. Second, the EU has imposed countervailing duties on Indonesian biodiesel, finding that Indonesia's export tax on crude palm oil constitutes a subsidy to Indonesian biodiesel producers. The EU's apparently inelastic demand for protection raises two questions: First, when domestic political bargains rest on both protectionist and non-protectionist motives and policies have both protectionist and non-protectonist effects, what are the welfare consequences of restraining only overt protectionism? Second, under what circumstances may regulatory approaches be even less desirable than duties for addressing combined protectionist and environmental interests, and would the WTO have the right powers to discipline them in an environmentally sound way?
\end{abstract}

\section{Introduction}

The conflict between trade and the environment has been a long simmering one. Critics allege that trade liberalization undermines core environmental values through a variety of different mechanisms. Trade liberalization, for instance, can shift production to countries with relatively poor environmental policies. Trade rules may limit governments' ability to subsidize green technology. And trade tribunals may interpret trade rules to constrain governments' freedom to pursue environmental objectives in ways that restrict trade or discriminate against foreign commerce. The conflict dates back decades and includes, among others, the Tuna-Dolphin disputes, Shrimp-Turtle, Canada-Renewable Energy, and most recently the panel decision in United StatesRenewable Energy (India). ${ }^{1}$ Similar complaints come from those working in policy domains such as human rights, development, and economic inequality.

The conventional response to these criticisms is to argue that trade rules do not limit governments' freedom to pursue other policy objectives, such as environmental protection or domestic

\footnotetext{
${ }^{1}$ See Howse and Nevin (2003); Charnovitz and Fischer (2015); and Coglianese and Sapir (2017) for analysis of these cases.

(C) The Author(s), 2020. Published by Cambridge University Press. This is an Open Access article, distributed under the terms of the Creative Commons Attribution licence (http://creativecommons.org/licenses/by/4.0/), which permits unrestricted re-use, distribution, and reproduction in any medium, provided the original work is properly cited.
} 
economic development. Rather, trade rules structure how governments pursue those objectives. So long as a government policy does not run afoul of trade rules, governments may adopt any policy they like without penalty. Even better, designing policies to comply with trade rules may make such policies more effective by allowing them to operate against a background of economic efficiency.

In essence, the dispute between these two positions is over how trade law should respond to 'Baptist-Bootlegger' coalitions (Yandle, 1983). ${ }^{2}$ Political coalitions that support environmental (or other) objectives often depend on the support of those seeking economic protection .The resulting regulation rests on mixed motives and often has mixed effects. On the one hand, it pursues a generally permissible non-trade (e.g., environmental) purpose, and on the other hand, it pursues an impermissible protectionist one. How should trade law respond to these mixed-motive policies?

The WTO panel report in EU-Biodiesel (Indonesia), along with the underlying facts, presents a quintessential example of such mixed motives. ${ }^{3}$ In this article, we ask whether the straightforward application of antidumping rules to facts similar to those present in EU-Biodiesel (Indonesia) increases welfare. The article proceeds in four sections. Section 2 describes efforts in both the EU and Indonesia to develop a domestic biodiesel industry for both environmental and economic development reasons. Facing the common practice of tariff escalation - the differentiation of import tariffs so that such commodities face lower tariffs than the more processed goods - and to promote domestic use of their commodities, Indonesia (and, in a related case, Argentina) deployed a differential export tax (DET). The EU found these policies - which depressed domestic prices of crude palm oil (CPO) in Indonesia (and soybean oil in Argentina) but raised the costs of these inputs for the EU - upended their efforts to develo their own biodiesel refining industries. Initially, the EU attempted to counteract this de facto subsidization by Indonesia and Argentina through antidumping duties, effectively meeting a border tax-based distortion with a border tax-based solution that would protect its domestic industries.

Section 3 describes Indonesia's successful challenge to these antidumping duties. Section 4 explains the EU's response. The adverse decision has done nothing to reduce the demand for protection by the EU. Rather, it has simply shifted the form of protection from antidumping duties to environmental regulation and countervailing duties. Section 5 questions whether the WTO is equipped to manage the balance of objectives raised by EU-Biodiesel (Indonesia) and cases like it. We make two points. First, the competing tariffs likely had environmental benefits, with the DET aiding Indonesia's transition toward bio-based energy and the antidumping duties aiding a shift in the EU toward second-generation biofuels. Second, the application of antidumping rules in the case of mixed-motives, such as the one at issue here, can push governments to choose regulations that are more convoluted as the means of protection. Instead of relatively transparent duties, the decision in EU-Biodiesel (Indonesia) has incentivized the EU to resort to regulatory protection. And because that regulatory protection has a plausible basis in environmental policy, a fight over its compatability with WTO law puts greater pressure on the WTO's legitimacy at a time when the WTO can least afford such a struggle.

\section{Developing a Biodiesel Industry}

Both the European Union (EU) and Indonesia have long sought to foster the development of a domestic biofuel industry. This section briefly sets forth the history of each country's support for

\footnotetext{
${ }^{2}$ As Yandle (1983) explains, political coalitions often form between two groups that want the same thing for different reasons. Bootleggers wanted laws that closed bars and liquor stores on Sundays in order to boost their own illicit alcohol sales. In other words, they wanted economic protection. Baptists wanted the same laws in the service of a moral purpose, sobriety. The analogy has often been used to describe coalitions of environmentalists and protectionists (DeSombre, 1995; Kellow, 1999; Yandle and Buck, 2002).

${ }^{3}$ Panel Report, European Union-Antidumping Measures on Biodiesel from Indonesia (EU-Biodiesel (Indonesia)), WT/ DS480/R (25 January 2018).
} 
its biofuel sector. As we explain below, the EU has appealed to both environmental and economic development objectives to justify its support. For Indonesia, energy security, industrial support, and mitigation of greenhouse gases were likewise its objectives. Both have provided support through a range of policy tools, including subsidies, environmental and energy regulations, and, ultimately, trade policies reflecting their respective domestic industrial interests.

\subsection{The EU's Renewable Energy Directive}

In 2003, the EU set goals for expanding usage of renewable transportation fuels starting with the Biofuel Directive. ${ }^{4}$ It called for indicative targets of $2 \%$ of petrol and diesel consumption by the end of 2005 and $5.75 \%$ by the end of 2010 . The Directive's justification rested on a mix of environmental and economic development grounds. For instance, the Directive noted that '[g]reater use of biofuels for transport forms a part of the package of measures needed to comply with the Kyoto Protocol' (Preamble, para. 6). At the same time, the Directive also noted that '[p] romoting the use of biofuels ...could create new opportunities for sustainable rural development ... and could open a new market for innovative agricultural products' (Preamble, para. 15). To that end, the Directive cited support, in the form a 1998 European Parliament resolution, for 'a package of measures,including tax exemption, financial assistance for the processing industry and the establishment of a compulsory rate of biofuels for oil companies' as a means of expanding the market share of biofuels.

In April 2009, the EU adopted the Renewable Energy Directive. ${ }^{5}$ The Directive required that $20 \%$ of the EU's total energy consumption, and $10 \%$ of its energy consumed in the transport sector, come from renewable sources by 2020. The Renewable Energy Directive was one of the EU's primary vehicles to reduce its greenhouse gas emissions and satisfy its international climate obligations. Although principally justified on climate grounds, the Directive also cited non-environmental considerations. Prominent among these justifications was the 'opportunities for growth and employment that investment in regional and local production of renewable energy bring[s]' as one reason for promoting renewable energy. The Directive went on:

When favouring the development of the market for renewable energy sources, it is necessary to take into account the positive impact on regional and local development opportunities, export prospects, social cohesion and employment opportunities.

On its face, then, the EU's support for the promotion of renewable energy was justified by both environmental and economic development considerations.

The biofuel sector was one of the sectors expected to benefit from the incentives the Directive established. Satisfying the $10 \%$ renewable energy requirement in the transport sector would require significantly increased use of biofuels within the EU, creating a market opportunity for biofuel producers. Within the EU, biodiesel (as opposed to bioethanol) has been the predominant biofuel. At the time the Directive came into effect, the EU was also the world's leading producer of biodiesel and its productive capacity only increased following the Renewable Energy Directive. But while the EU's production of biodiesel increased by 44\% from 2007 to 2010, production in other parts of the world soared. Of particular note, Argentinian production increased by a factor of 10 and Indonesian production increased by a factor of 8 (Hamelinck et al., 2012).

At the same time, this increased demand for biofuels presented an environmental risk. Biofuel production can lead to indirect land use changes (ILUC) that have significant negative environmental consequences (Fargione et al., 2008). Indeed, the increased cultivation of palm oil in Indonesia has been linked to the loss of upwards of $30 \%$ of the nation's forests, causing further

\footnotetext{
${ }^{4}$ Directive 2003/30/EC, use of biofuels and renewable fuels.

${ }^{5}$ Directive 2009/28/EC of the European Parliament and of the Council (23 April 2009).
} 
losses to biodiversity and increased greenhouse gas emissions, among other harms (Wicke et al., 2011). Similarly, cultivation of biofuel inputs can displace the cultivation of food, leading to an increase in food prices (Solomon, 2010: 125-127). Finally, biofuels may also be relatively inefficient from an energy perspective, given the effort and resources necessary to produce biofuels in the first place (Solomon, 2010: 123-125).

To address these risks, the initial 2009 Renewable Energy Directive also established sustainability criteria that biofuels must meet in order to fulfill the renewable energy targets. In particular, Article 17 of the Directive requires that, in order to count towards the renewable energy targets established by the Directive, biofuels must achieve a 35\% (rising to 50\% and then $60 \%$ ) reduction in greenhouse gas emissions relative to conventional fuels and not be produced through carbon-intensive land use practices, such as deforestation.

As one might expect, the Renewable Energy Directive, and the regulations that preceded it, stimulated a sharp increase in consumption of biofuels, specifically biodiesel, within the EU. EU production of biodiesel rose to meet this new demand. At the same time, however, imports of biodiesel from overseas also increased dramatically. As Figure 1 shows, the result of this increase in imports was that between 2009 and 2011 domestic production of biodiesel slowed and even declined slightly, even as domestic consumption continued to rise.

As Figure 1 also attests, these trends reversed themselves in 2011. Domestic production once again rose, while imports have since then fluctuated somewhat but have largely remained flat. The year 2011 also falls within the period in which the EU began to make aggressive use of trade remedies to defend its domestic market against imported biodiesel. In July 2009, the EU imposed definitive antidumping duties on US biodiesel. ${ }^{6}$ The EU followed these duties up in May 2011 with additional duties designed to prevent circumvention of the 2009 duties. ${ }^{7}$ After that, the EU turned its attention elsewhere.

\subsection{Indonesia's Policies for Palm Oil and Biodiesel}

Indonesia is the world's largest producer of palm oil, and the palm oil represents the country's most important agricultural product. In addition to being an important export product, palm oil is a local staple for cooking. Since 1994, shortly after it began to liberalize trade, Indonesia has sought to promote price stability and affordability for domestic consumers of palm oil by deploying CPO export taxes. This export tax varies based on the differential between world prices - which can fluctuate greatly with foreign exchange and energy markest - and a base price. $^{8}$ From 2000 to 2007, this tax was relatively insignificant, but as global demand for palm oil as an energy source picked up, so did world prices and thus the export tax (Rifin, 2014).

An additional motivation for the CPO export tax was to encourage development of domestic downstream industries using the input, including refined palm oil and subsequently biodiesel. Downstream industries generate more value added and are thus attractive. For this same reason, most importing countries impose higher tariffs on downstream products than on commodities a practice known as tariff escalation. To counter the distortions of tariff escalation, large developing countries often use export taxes, which are generally allowed under multilateral trade rules (EU, 2016). For example, while the EU has no tariff on crude palm oil, an input its own domestic biodiesel industry can use, refined products face a $6.5 \%$ import tariff. ${ }^{9}$ The Indonesian differential export tariff offset this differential import tariff. The export tax on

\footnotetext{
${ }^{6}$ Council Regulation (EC) No. 599/2009 of 11 March 2009.

${ }^{7}$ Council Implmenting Regulation (EU) No. 444/2011 of 5 May 2011.

${ }^{8}$ Minimum reference prices (below which export taxes were zero) were $\$ 435$ from July 1997, raised to $\$ 550$ in September 2007, $\$ 700$ in November 2008, and \$750 in September 2011 (Rifin, 2014).

${ }^{9}$ Source: EU Market Access Database (accessed August 2019). https://madb.europa.eu/madb/euTariffs.htm? productCode=15111010\&country=ID and https://madb.europa.eu/madb/euTariffs.htm?productCode=3826009019\&country=ID.
} 


\section{EU-28}

14,000

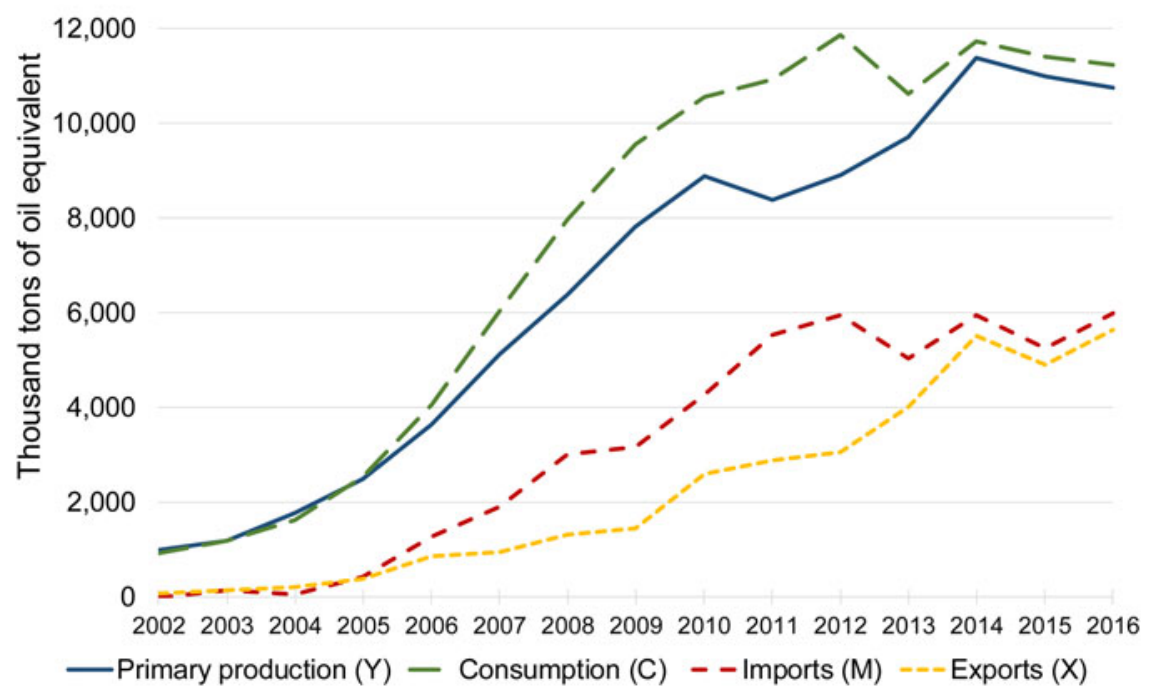

Figure 1. EU biodiesel production, consumption, and trade Source: Eurostat nrg_107a.

crude palm oil only exceeded $6.5 \%$ when global CPO prices rose sharply. Figure 2 shows the evolution of global CPO prices (right axis) and the differences between Indonesian and global biodiesel prices.

In 2009, at the same time as the EU, Indonesia began to phase in its own renewable blend mandate for diesel, requiring conventional diesel sales to incorporate a minimum content of biodiesel, rising from $1 \%$ to $10 \%$ by 2013 . A variety of tax incentives were offered to producers, while the provision and distribution of biofuel was guaranteed by the government of Indonesia, with the Ministry of Energy and Mineral Resources setting the price of biofuel (USDA, 2010). Thus, Indonesia implemented major aspects of its program in a non-market-based way, making prices non-transparent and also resulting in structural inefficiencies (USDA, 2018). Still, with domestic support and global demand, Indonesia became a major producer and exporter of biodiesel as of 2011, and the industry continued to grow in subsequent years, primarily due to expanding domestic consumption (IRENA, 2017).

\subsection{The EU's Imposition of Antidumping Duties on Biodiesel}

In August 2012, the European Commission initiated an antidumping investigation into Argentinian and Indonesion biodiesel in response to a complaint filed by the European Biodiesel Board (EBB). ${ }^{10}$ The complaint alleged the imports of biodiesel from Argentina and Indonesia were being sold in Europe for less than the fair value in their home markets and that these imports caused injury to European biodiesel producers.

The WTO's Antidumping Agreement provides that dumping occurs when the 'export price' of a good is below the 'normal value' of that good. ${ }^{11}$ In making a determination as to whether

\footnotetext{
${ }^{10}$ Crowley and Hillman (2018) provide similar background in the context of the WTO challenge brought by Argentina.

${ }^{11}$ The amount of the difference between the export price and normal value is referred to as the dumping margin. For example, if Indonesian biodiesel sells for \$12 in Indonesia but only \$10 in Europe, there is a dumping margin of \$2. In addition to finding that dumping is occurring, an investigating authority (in this case the European Commission) must also find
} 


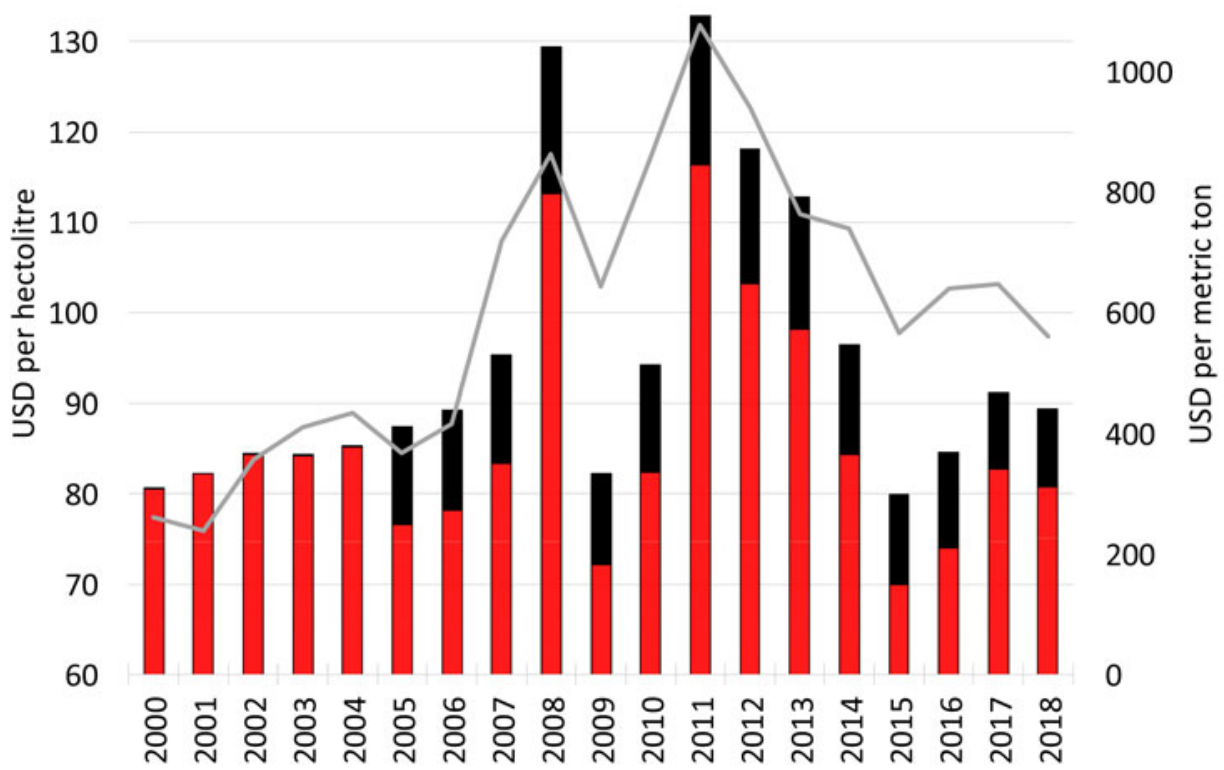

Indonesian biofuel price Global biofuel price —Global CPO price (right axis)

Figure 2. Biofuel and Crude Palm Oil (CPO) prices

Source: OECD-FAO.

dumping had occurred, a domestic investigating authority like the European Commission must, among other things, construct the 'normal value' of the product in question. In most cases, the Antidumping Agreement requires that an investigating authority equate normal value with 'the comparable price, in the ordinary course of trade, for the like product when destined for consumption in the exporting country' - in other words, the home market price of the good in question. ${ }^{12}$ However, the Antidumping Agreement allows an investigating authority to construct normal value using an alternate method either when there are no home market sales of the product in the ordinary course of trade, or 'when, because of the particular market situation or the low volume of the sales in the domestic market of the exporting country [i.e., Indonesia], such sales do not permit a proper comparison' ${ }^{13}$ If either of those conditions apply, an investigating authority may construct normal value by using either the prices in a third country market or the costs of production (COP) plus selling, general and administrative costs, and a reasonable profit.

The Commission determined that the Argentinian and Indonesian biodiesel markets were so heavily regulated that home market prices could not serve to construct normal value. Instead, the Commission elected to use the COP method. Doing so required the Commission to calculate the costs of certain inputs used to make biodiesel in Argentina and Indonesia. In Argentina, the key ingredient is soybeans and soybean oil, while in Indonesia the key ingredient was crude palm oil. The EBB argued that the prices of these two inputs were themselves too distorted to be reliable. During its provisional investigation, the Commission concluded that it did not have sufficient

that the dumped imports cause material injury to the domestic producers of the like good in question. If the investigating authority makes these findings, it can impose antidumping duties up to the margin of dumping ( $\$ 2$ per gallon in the example above).

${ }^{12}$ Antidumping Agreement art. 2.1.

${ }^{13}$ Antidumping Agreement art. 2.2. 
information to reach a conclusion on that point, and instead relied on producers' actual costs of, in Indonesia, palm oil. In May 2013, the Commission's resulting provisional decision imposed antidumping duties at margins of between $0 \%$ and $9.6 \%$.

In the final phase of its investigation, though, the Commission reached a different conclusion. The EBB argued that the DETs that both Argentina and Indonesia had in place depressed the prices of soybeans and palm oil, respectively. In Indonesia, the Commission found that during the investigation period (1 July 2011 through 30 June 2012) biodiesel exports were taxed between $2 \%$ and $5 \%$, while crude palm oil exports were taxed between $15 \%$ and $20 \%$. The export tax on palm fruit, from which crude palm oil comes, was $40 \% .{ }^{14}$ As figure 2 shows, this period overlaps with the peak of global CPO prices. Because the DET rose with global prices, the EU's investigation was based on a limited period of time with abnormally high global CPO prices.

Nevertheless, the Commission concluded that the DETs limited the export of palm fruit and palm oil, increasing the quantity of domestic supplies and thereby reducing the price for local refiners. As a result, the Commission found that the domestic price of crude palm oil was below the international reference price at an amount very close to the export tax. The Commission made similar findings with respect to soybeans in Argentina. ${ }^{15}$

Having concluded that the domestic markets for soybeans and palm oil were distorted, the EU elected to disregard the actual costs producers paid for these inputs. Instead, with respect to Indonesia, the Commission substituted the reference price for crude palm oil published by the Indonesian government, which used international prices to calculate an average reference price. By using this higher number, the Commission shifted the dumping margins upward in its final decision to a range of $8.8 \%$ to $23.3 \%{ }^{16}$

As Crowley and Hillman (2018) have noted, Argentina and Indonesia likely imposed DETs in order to move up the value chain by exporting more of a higher value-added commodity (biodiesel) and less of a less valuable commodity (soybeans or palm oil). They also aided their biodiesel industry by granting a de facto subsidy. The high export tax on biodiesel inputs kept producers' costs for those inputs artificially low, offsetting the escalation in the EU's tariff schedule from palm oil to biodiesel. As Crowley and Hillman also note, this de facto subsidy might not easily fit within the WTO's Subsidies and Countervailing Measures Agreement, because the government itself was not providing a financial contribution to biodiesel producers. Instead, the export tax effectively redistributed from soy or palm oil producers to biodiesel producers in the form of lower prices for the raw inputs. The potentially restrictive definition of what kinds of governmental financial interventions count as a subsidy under the SCM Agreement likely explains why the EU initially chose to pursue antidumping, rather than countervailing, duties.

\section{Can Antidumping Duties Reach Upstream Price-Distorting Measures?}

Indonesia requested consultations with the EU in June 2014, raising a host of challenges to the EU's antidumping methodology. The DSB established a panel in August 2015, although the panel ultimately deferred its proceedings until 2017 so that it might operate with the benefit of the Appellate Body's decision in EU-Biodiesel (Argentina). As in EU-Biodiesel (Argentina), Indonesia's central claim turned on whether an investigating authority using a COP method is required to use actual costs, as Indonesia argued, or could use alternative data when a producer's

\footnotetext{
${ }^{14}$ Commission Implementing Regulation (EU) No. 1194/2013 imposing a definitive anti-dumping duty and collecting definitively the provisional duty imposed on imports of biodiesel originating in Argentina and Indonesia (19 November 2013), para. 69.

${ }^{15}$ For a fuller description of the Commission's findings with respect to Argentina, see Crowley and Hillman (2018).

${ }^{16}$ The EU ultimately imposed antidumping duties ranging from $8.8 \%$ to $20.5 \%$, corresponding to the injury margins the Commission found.
} 
actual costs reflect serious distortions to the market, as the EU argued. In more general terms, the dispute asked how much flexibility an investigating authority has to impose antidumping duties in order to offset advantages a producer enjoys from operating within a highly distorted market.

Crowley and Hillman (2018) have already recounted the Appellate Body's central reasoning in EU-Biodiesel (Argentina), which we briefly summarize below. Indonesia argued that, because the EU had taken the same approach to calculating Indonesian producers' costs as Argentinian producers' costs, Indonesia should prevail in its main claims for the same reasons Argentina did. The panel agreed with Indonesia, finding no relevant differences between the facts of Argentina's and Indonesia's cases, and thus found for Indonesia. ${ }^{17}$

Like Argentina, Indonesia successfully argued that the EU's antidumping methodology violated Articles 2.2 and 2.2.1.1 of the Antidumping Agreement. Article 2.2 allows an investigating authority to use 'the cost of production in the country of origin plus a reasonable amount for administrative, selling, and general costs and for profits' when home market prices are unavailable or inappropriate. When an investigating authority chooses to use a costs of production methodology, Art. 2.2.1.1 requires that 'costs shall normally be calculated on the basis of records kept by the exporter or producer under investigation'.. Indonesia did not dispute the use of the COP methodology. Instead, it argued that the EU's decision to disregard the prices for palm oil found in the producers' record, and instead substitute the reference price published by the Indonesian government based on international transactions, violated both of these requirements. Because the reference prices were based on international sales, they did not reflect 'the cost of production in the country of origin [i.e., Indonesia]'.

The EU was also not basing its cost calculations 'on the basis of records kept by the exporter or producer'. Article 2.2.1.1 does allow an investigating authority to deviate from those records if they are not in accordance with the generally accepted accounting principles of the exporting country' or do not 'reasonably reflect the costs associated with the production and sale of the product under consideration'. The EU argued that Indonesia's DET system meant that the price of palm oil found in Indonesian producers' record did not 'reasonably reflect' the actual cost of palm oil. The $\mathrm{AB}$ rejected this argument as applied to soybeans in Argentina's case, finding that the phrase 'reasonably reflects the costs' means 'whether the records kept by the exporter or producer suitably and sufficiently correspond to or reproduce those costs incurred by the investigated exporter or producer' (para. 6.26). The panel in Indonesia's case saw 'no basis to deviate from the findings by the panel in EU-Biodiesel (Argentina)' (para. 7.26)

Indonesia also objected to how the EU calculated profits in its COP calculation. Recall that Article 2.2 requires that profits be added to the cost of production when COP is used to calculate normal value. When profits cannot be determined from actual records due to an absence of sales in the ordinary course of trade, Article 2.2.2(iii) permits an investigating authority to use 'any other reasonable method [to calculate profits], provided that the amount for profit so established shall not exceed the profit normally realized by other exporters or producers on sales of products of the same general category in the domestic market of the country of origin'. Indonesia argued that the EU violated Article. 2.2.2(iii) because (1) it failed to calculate a profit cap and (2) its method of calculating profits was not reasonable. On the first point, Indonesia argued - and the panel essentially agreed - that if an investigating authority did not calculate a profit cap, i.e., 'the profit normally realized by other exporters or producers', interested parties would not be able to tell whether the condition set out 2.2.2(iii) had been satisfied.

On the second point, Indonesia argued that it was unreasonable for the EU to apply a $15 \%$ profit margin to Indonesian producers. The EU had arrived at this profit margin by looking

\footnotetext{
${ }^{17}$ Indonesia also claimed that the EU violated Articles 3.1 and 3.2 of the Antidumping Agreement because it did not base its determination of injury on an objective examination of the effect of Indonesian imports on prices within the EU for biodiesel. The panel rejected one rationale for Indonesia's claim, while accepting another (para. 8.1). We focus on the claims involving Article 2.
} 
to its own biodiesel industry in 2004-2006, an early stage of biodiesel development within the EU that EU authorities thought comparable to the stage of development of the biodiesel sector in both Argentina and Indonesia. Again following the $\mathrm{AB}$ in EU-Biodiesel (Argentina), the panel ruled in favor of the EU. The panel emphasized the broad discretion conferred on investigating authorities by the reasonableness standard of Article 2.2.2(iii). The reasonableness inquiry asks only 'whether the investigating authority's determination of the amounts for profits is the result of a reasoned consideration of the evidence before it, rationally directed at approximating the profit margin to what would have been realized if the product under consideration had been sold in the ordinary course of trade in the exporting country' (para. 7.79). Although Indonesia had presented evidence that the Indonesian biodiesel industry during the investigation period (2011-2012) was not comparable to the EU biodiesel industry in 2004-2006, the panel ruled that the investigating authorities approach to evaluating the evidence was, indeed, reasonable.

Overall, the panel's approach to the dispute reflects a classic legal analysis, albeit one that hits on concerns with the DSB. First, the panel relied heavily on the AB's decision in EU-Biodiesel (Argentina), essentially following the AB's decision as precedent. Although treating past decisions as precedent has become controversial with the United States, the case for the application of precedent was especially strong. The EU had conducted a single investigation into both Argentina and Indonesia, which had similar DET schemes. The EU and Indonesia had also both at least tacitly acknowledged the relevance of the AB's decision in EU-Biodiesel (Argentina), in Indonesia's case by requesting a delay in the proceedings until the $\mathrm{AB}$ issued its decision and in the EU's case by not objecting to that request.

The panel's decision also hewed closely to the text and purpose of the Antidumping Agreement. Crowley and Hillman criticize the AB's decision in EU-Biodiesel (Argentina) for putting investigating authorities in a difficult position: 'It is hard to imagine how any IA would ever be able to prove that the domestic prices cannot be used due to distortions or unavailability and at the same time find a surrogate price that it can prove represents those same domestic prices' (2018, p. 203). The authors' analysis, though, arguably misconstrues the purpose of the Antidumping Agreement.

The Antidumping Agreement is concerned with private conduct - the pricing decisions of private firms. Given that concern, as well as the text of the provisions at issue, the decisions in EU-Biodiesel (Argentina) and EU-Biodiesel (Indonesia) make sense. A private producer does not control whether government taxation distorts the prices at which it purchases inputs. Of course, if the government actually subsidizes the purchase of the input directly (or if tax-based distortions, like those created by the DET, are treated as subsidies), that subsidy may be reached under the SCM Agreement. But the problematic action under the SCM Agreement is the government subsidy, not the resulting pricing decision by the private producer, even if the mechanism for addressing the government's conduct is a countervailing duty that affects the price of the product. The text of the Antidumping Agreement reflects this distinction between distorted prices of the product in question and distorted input prices. The former is expressly a reason to deviate from home market prices in calculating normal value under Article 2.2. The latter would require reading Article 2.2.1.1, a provision about the records of the investigation's subjects, as authorizing a broader inquiry into background economic conditions.

Crowley and Hillman (2018) are right, of course, to note that a tax-distorted input is trade distorting in the same way as countervailable subsidies can be (indeed, as we explain below, the EU ultimately decided to treat the DET as a subsidy under the SCM Agreement). It is also true that governments have increasingly looked to the flexibility afforded by the Antidumping Agreement as a way of addressing non-market situations. Moreover, given U.S. trade policies, the fate of the WTO may hinge on reaching agreement on clearer and more expansive rights for governments to respond to unconventional or difficult-to-prove subsidies.

But if WTO members criticize panels and the AB for departing from the text of the WTO agreements, especially in trade remedies cases, they can hardly be heard to complain when a 
panel or the $\mathrm{AB}$ enforces the text of the agreement. In both EU-Biodiesel (Argentina) and EUBiodiesel (Indonesia), the adopted reports do just that by enforcing the Antidumping Agreement's focus on the costs of the private producers actually under investigation, and not the broader economic conditions that impact those costs. Nor does this indicate a particular bias by the panels in these cases. The decision in the EU's favor on the reasonableness of its profit methodology under Article 2.2.2(iii) indicates that where the Antidumping Agreement gives investigating authorities discretion, the panel will respect that discretion.

Finally, Indonesia also argued that the EU violated Article 2.3 by not correctly constructing the export price for one particular producer. Export prices, of course, have the opposite effect on dumping margins from normal value. While a higher normal value increases the dumping margin, a higher export price decreases the dumping margin (and hence a lower export price increases the dumping margin).

The parties agreed that the Article 2.3 requires an investigating authority to construct the export price by looking to the price charged to the first independent buyer. They disagreed, however, as to the meaning of the term 'price'. In the case of the producer in question, certain Italian purchasers of biodiesel had agreed to pay a price premium because the biodiesel in question palm fatty acid distillate(PFAD)-based biodiesel - was eligible to be 'double counted' under the EU's Renewable Energy Directive, which provides that certain biofuels 'shall be considered to be twice their energy content'. ${ }^{18}$ The EU had disregarded this price premium, reasoning that the premium had no link to the product (para. 7.111). The panel rejected this reasoning and found for Indonesia. It concluded that the physical characteristics of the biodiesel, namely that it was made from PFAD, made purchasers willing to pay more for the product. By operation of their own domestic regulations, such purchasers could use half the amount of PFAD to satisfy regulations regarding blending biofuels with ordinary mineral diesel.

This finding makes sense of the relationship between regulations and market prices. Markets depend on the existence of government regulation both to function and to determine the value of products and services. The value of property, for instance, depends on government-protected property rights. The value of a drug depends on whether regulatory authorities have approved the drug for sale on the market. Similarly, where a government implements regulations that create demand for certain environmental goods, those environmental goods will be more valuable in the market. An investigating authority can hardly complain when that value manifests in the price a purchaser is willing to pay.

\section{The EU Turns to Environmental Regulations and Subsidies Rules}

A key question after these cases is the extent to which countries can support environmental goods while also protecting for their own economies the economic opportunities created by environmental goods. ${ }^{19}$ As the preamble to the Renewable Energy Directive makes clear, the turn to biofuels in Europe was motivated by a mix of environmental, energy security, and domestic economic development objectives. When the international trade regime made it difficult to achieve the kinds of domestic economic growth that proponents wanted, the domestic industry looked to trade policy for protection. In the wake of Indonesia's and Argentina's victories at the WTO, imports of biodiesel from those countries have once again surged. As a result, the $\mathrm{EU}$ is looking at a mix of trade policy and environmental policy tools to protect its market from Indonesian and Argentinian imports that, in its view, both threaten local production and cause unintended environmental harm.

\footnotetext{
${ }^{18}$ Directive 2009/28, Annex IX.

${ }^{19}$ Crowley and Hillman (2018) take on a different question, namely the extent to which trade remedies can be used to address the serious distortions of costs and prices that work to the benefit of foreign producers operating in non-market or heavily regulated environments.
} 
In September 2017, following the adoption of the Appellate Body report in EU-Biodiesel (Argentina), the EU initially recalculated and reimposed antidumping duties on Argentinian biodiesel imports. ${ }^{20}$ In 2018, however, after the DSB's adoption of the panel report in EU-Biodiesel (Indonesia), the EU decided to terminate entirely the duties on Argentinian and Indonesian imports. ${ }^{21}$ At the same time, the EU dropped an appeal to the European Court of Justice of a 2016 General Court decision that had already annulled the duties with respect to the litigants in that case. ${ }^{22}$

The result has been a dramatic increase in biodiesel imports. As Figure 4 below demonstrates, in 2018 biodiesel imports into the EU roughly tripled from the year before. Argentina and Indonesia were by far the largest beneficiaries. As a consequence, the European Commission has been under pressure to stem the flow of imports. The Commission's efforts have taken two paths.

\subsection{Environmental Regulations}

Even before the adverse decisions by the DSB, the Commission amended its regulations on biofuels to strengthen the sustainability criteria necessary for biofuels to count toward satisfying EU targets. In 2015, the EU amended the directive to cap the amount of biofuels that could come from foodstocks at $7 \%$ of total energy consumption in the transport sector (the transport sector had an overall goal of achieving $10 \%$ of its energy consumption from renewable sources). ${ }^{23}$ The 'recast' Renewable Energy Directive in 2018 raised the transport sector target to 14\%, while retaining the foodstocks limits and further reinforcing the sustainability criteria of bioenergy, including provisions on the negative direct impact that the production of biofuels may have due to ILUC. ${ }^{24}$ Critics had long alleged the use of food-based biofuels - such as those made from soy, palm oil, or rapeseed oil (the primary stock for first-generation biofuels produced in the EU) - cause more greenhouse gas emissions than they save through deforestation, while increasing the price of food at the same time. The 2018 Renewable Energy Directive requires the gradual phasing out by 2030 of biofuels that create a high risk of ILUC. ${ }^{25}$ Although EU members will still be allowed to import such fuels, they will no longer count as renewable fuels for purposes of satisfying the renewables mandate. As a result, the incentive to import such fuels will be dramatically lessened relative to fuels that will count toward the renewable mandate.

Although the 2018 Renewable Energy Directive did not single out any particular fuels as high risk, it directed the Commission to promulgate standards for assessing those fuels that posed a high risk of ILUC and for certifying those that create only a low risk. In March 2019, the Commission promulgated the required standards. ${ }^{26}$ At the same time, the Commission also conducted a study of deforestation arising from the cultivation of biofuels. ${ }^{27}$ The Commission concluded that palm oil cultivation has resulted in significantly more deforestation and ILUC than

\footnotetext{
${ }^{20}$ Commission Implementing Regulation (EU) 2017/1578 amending Implementing Regulation (EU) No. 1194/2013 imposing a definitive anti-dumping duty and collecting definitively the provisional duty imposed on imports of biodiesel originating in Argentina and Indonesia (18 September 2017).

${ }^{21}$ Commission Implementing Regulation (EU) 2018/1570 terminating the proceedings concerning imports of biodiesel originating in Argentina and Indonesia and repealing Implementing Regulation (EU) No 1194/2013 (18 Oct. 2018). The EU initially provided exemptions for some producers in March 2018.

${ }^{22}$ Ibid. para. 1(3)-(4).

${ }^{23}$ Directive 2009/28/EC of the European Parliament and of the Council of 23 April 2009, art. 3.4(d), as amended by Directive (EU) 2015/1513 of the European Parliament and of the Council of 9 September 2015.

${ }^{24}$ Directive (EU) 2018/2001 of the European Parliament and of the Council of 11 December 2018 on the promotion of the use of energy from renewable sources.

${ }^{25}$ Ibid. article 26.2.

${ }^{26}$ Commission Delegated Regulation (EU) C(2019) 2005/1013409 supplementing Directive (EU) 2018/2001 (13 March, 2019), https://ec.europa.eu/energy/sites/ener/files/documents/2_en_act_part1_v3.pdf.

${ }^{27}$ Ibid. Annex - C(2019) 2055/1013407.
} 


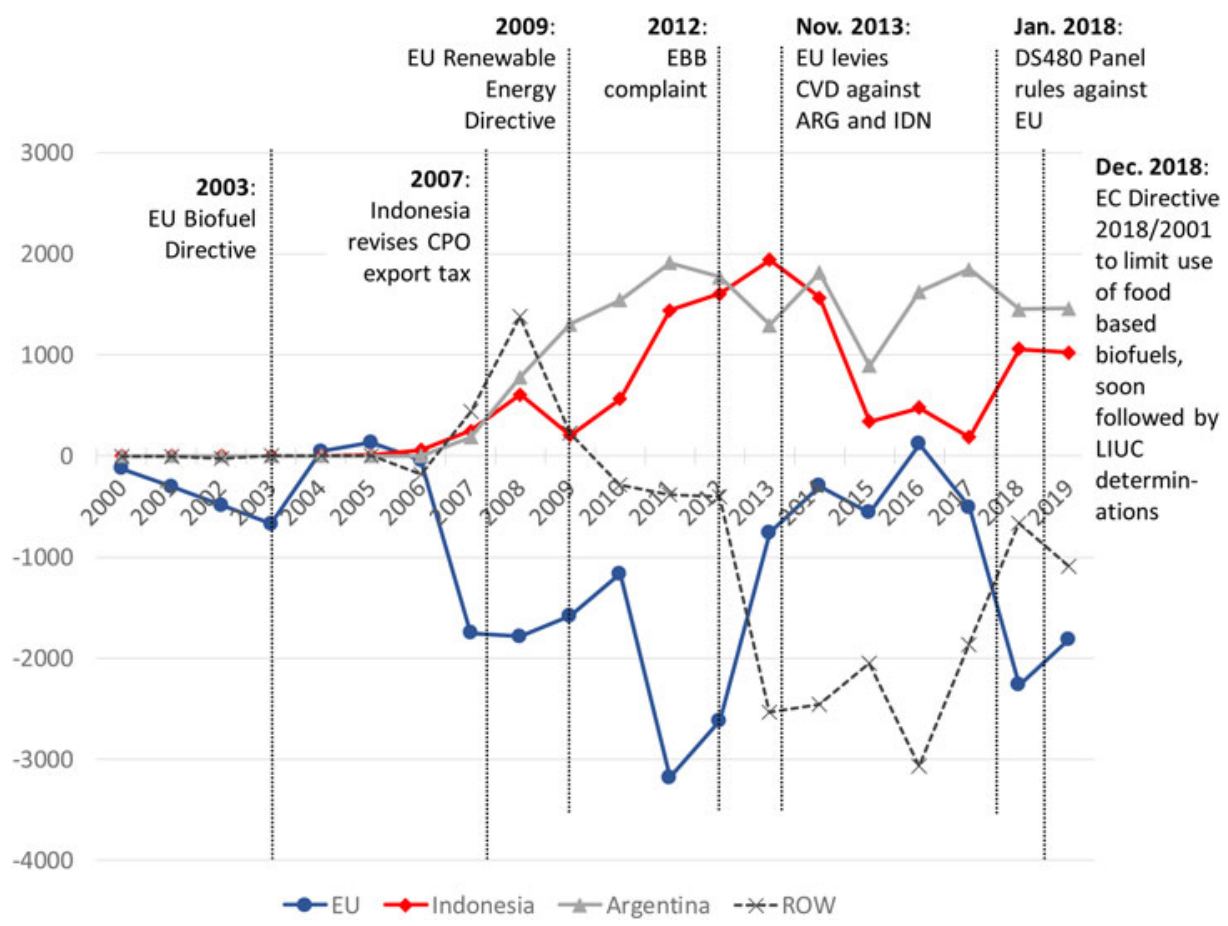

Figure 3. Trade balance (production minus consumption) by country and timeline of interventions

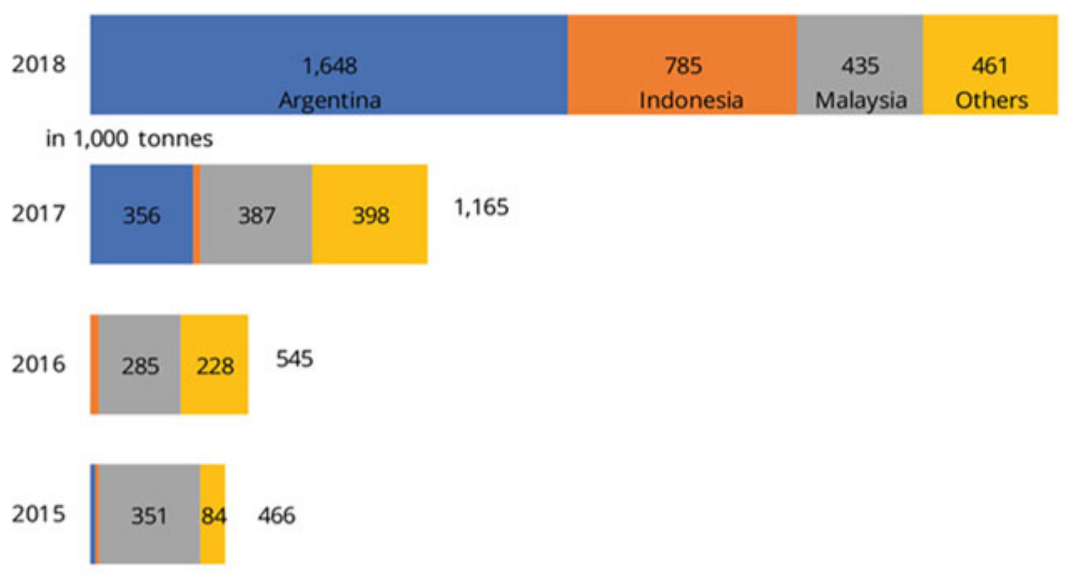

Figure 4. EU biodiesel imports

Source: https://bioenergyinternational.com/markets-finance/european-biodiesel-imports-from-argentina-and-indonesia-increase-sharply).

other biodiesel foodstocks. Together with the general criteria the Commission announced, the result was that the 2018 Renewable Energy Directive's phaseout for biofuels creating a high risk of ILUC applies to most palm oil, but not to soy or rapeseed, the stocks in Argentina and the EU respectively. The latter do, however, remain limited by the cap on foodstock sources. 
Predictably, both Indonesia and Malaysia (the second largest producer of palm oil after Indonesia) threatened retaliatory action. Indonesia in particular indicated that it would challenge the measure at the WTO as privileging local EU commodities such as rapeseed oil, as well as soy, at the expense of palm oil (Aisyah, 2019). Indonesia also claimed that the Commission's adopted methodology does not take into account features unique to tropical regions. The biodiesel industry in Indonesia has offered to fund a WTO dispute against the EU on these grounds, and is also reportedly considering filing a case in the European court system (Aisyah, 2019). However, due to the slow pace of implementation by the EU, no cases have been filed in either venue to date.

\subsection{Countervailing Duties Investigations}

The Commission has reinitiated trade remedies investigations into both Indonesian and Argentinian biodiesel. This time, however, the Commission proceeded through anti-subsidies investigations. In February 2019, the Commission imposed definitive countervailing duties on Argentinian imports. ${ }^{28}$ In particular, the Commission determined that Argentina provided a financial contribution to biodiesel exporters by 'entrusting' or 'directing' soybean farmers to provide soybeans to biodiesel producers at below market price. ${ }^{29}$ Argentina did so by essentially making it irrational for soybean farmers to export their product because of the extremely high export tariffs. ${ }^{30}$ Because Argentina used the export subsidy as a tool to induce soybean growers to comply with its stated policy of lowering the price of inputs for biofuels, the Commission concluded that the export tax amounted to a countervailable subsidy. ${ }^{31}$ At the same time, however, Argentina and the EU reached an agreement to suspend the duties for eight major Argentinian producers that agreed to minimum prices. ${ }^{32}$ As a consequence, Argentina will not contest at the WTO the Commission's innovative tactic of treating an export tax as a subsidy.

Similarly, the Commission initiated an anti-subsidies investigation into Indonesian biodiesel in December 2018, within a week of the issuance of the 2018 Renewable Energy Directive. ${ }^{33}$ The initiation followed a complaint by the EBB filed on 22 October 2018, just days after the EU issued its final regulation terminating antidumping duties against Indonesia. On 13 August 2019, the Commission imposed provisional countervailing duties of $8-18 \%$ after an investigation into four possible subsidies: (1) the direct transfer of funds granted through the Biodiesel Subsidy Fund; (2) provision of export financing and guarantees on preferential terms by the Indonesian Eximbank, and subsidies granted to the palm oil industry benefitting to biodiesel producers; (3) government revenue forgone or not collected; and (4) government provision of goods or services for less than adequate remuneration, such as CPO provision. ${ }^{34}$ This last subsidy is perhaps the most controversial. As it did in the case of Argentina, the Commission concluded that the export taxes and levies constitute a financial contribution by the Indonesian government. Specifically, the Commission concluded that Indonesia had entrusted its farmers with providing biodiesel producers CPO at below-market rates, a form of financial contribution under art. 1.1(a) (iv) of the SCM Agreement. ${ }^{35}$ To reach this conclusion, the Commission determined not only

\footnotetext{
${ }^{28}$ Commission Implementing Regulations (EU) 2019/244 para. 85, 2019 O.J. (L40) 1, https://eur-lex.europa.eu/legalcontent/EN/TXT/PDF/?uri=CELEX:32019R0244\&from=EN.

${ }^{29}$ Ibid. at para. 169.

${ }^{30}$ Ibid. at paras. $158-162$.

${ }^{31}$ Ibid. at para. 121.

${ }^{32}$ Commission puts in place duties on subsidized biodiesel from Argentina (19 February 2019), http://trade.ec.europa.eu/ doclib/press/index.cfm?Ibid=1979.

${ }^{33}$ Notice of Initiation of an anti-subsidy proceeding concerning imports of biodiesel originating in Indonesia (2018/C 439/ 15) para. 3, https://eur-lex.europa.eu/legal-content/EN/TXT/PDF/?uri=OJ:JOC_2018_439_R_0015\&from=EN.

${ }^{34}$ Commission Implementing Regulation (EU) 2019/1344 of 12 August 2019 imposing a provisional countervailing duty on imports of biodiesel originating in Indonesia, art. 3.1, https:/eur-lex.europa.eu/legal-content/EN/TXT/PDF/?uri= CELEX:32019R1344\&from=EN.

${ }^{35}$ Ibid. art. 3.3.3.2.
} 
that Indonesian producers sold CPO at below market prices, but also that the Indonesian government intended this result. ${ }^{36}$

The Indonesian government immediately condemned the action. Coming on the heels of the EU's determination that palm-based biodiesel would not count as a sustainable fuel under the new Renewable Energy Directive, a senior trade official said that the countervailing duties are part of a 'grand design' to ensure that 'vegetable oils produced from European soil [are not] rivaled by vegetable oil produced by tropical countries' (Christina, 2019).

Indonesia's objection sets up the possibility of a WTO case to test whether a DET can be a financial contribution within the meaning of the SCM Agreeement. A positive finding would open the door to considerably more expansive use of the SCM Agreement. Because the EU's theory is that the DET entrusted or directed private entities to provide funding - an action that counts as a financial contribution by the government under art. 1.1(a)(1)(iv) of the SCM Agreement - a WTO ruling in the EU's favor would allow governments to take action against a considerably wider range of government policies that redistribute resources among private actors. ${ }^{37}$ In particular, the SCM Agreement would become a much more useful tool for counteracting government-directed subsidies in countries with state-led economies.

\section{Implications}

The EU has thus managed to achieve a relatively high level of protection against both Indonesian and Argentinian biodiesel. Between 2013 and 2018, the EU relied on antidumping duties. Although it removed the antidumping duties in 2018, it immediately imposed countervailing duties on Argentina, has now imposed the same against Indonesia, and moved to eliminate palm-oil-based biodiesel altogether in the next decade through environmental regulations. The EU's turn to protection by other means raises two important issues. First, when domestic political bargains rest on both protectionist and non-protectionist motives and policies have both protectionist and non-protectonist effects, what are the welfare consequences of restraining only overt protectionism? Second, under what circumstances may regulatory approaches be even less desirable than duties for addressing combined protectionist and environmental interests, and would the WTO have the right powers to discipline them in an environmentally sound way?

\subsection{Political Economy and the Problem of Mixed Motives}

As described in Section 2, the EU's support for biofuels in the transportation sector has mixed motives. It sought both to reduce greenhouse gas emissions and to create economic opportunities within the EU. When the latter was threatened by foreign imports, the EU deployed trade policy in the form of antidumping duties to preserve the domestic economic opportunities, a move struck down by the panel in EU-Biodiesel (Indonesia). At that point, the coalition between environmental interests and economic interests morphed from a mixed motive coalition into one with mixed effects as well.

While from a legal point of view the panel's decision was a straightforward application of the Appellate Body's decision in EU-Biodiesel (Argentina), the welfare effects of the decision are murkier for two reasons. First, from a political economy point of view, support for environmental programs like the Renewable Energy Directive often hinge on building a political coalition that

\footnotetext{
${ }^{36}$ Ibid. The Commission, for instance, quoted an Indonesian official as saying that 'the aims of export duties [] is to ensure the availability of raw materials and to spur the growth of the domestic downstream palm oil industry'.

${ }^{37}$ Art. 1.1(a)(1)(iv) requires that the government entrust or direct a private body to make a financial contribution in essentially the same way as the government itself might. Thus, not all financial conttributions that occur at the direction of the government would qualify. Only those practices that 'would normally be vested in the government and the practice, in no real sense, differs from practices normally followed by governments' would count.
} 
extends beyond the environmental community. Environmental benefits are, after all, often public goods that are diffuse (much like the benefits of trade liberalization to consumers at large). Because of this fact, environmental policies that are welfare enhancing are often undersupplied by the political system. Tying domestic economic development to environmental concerns can solve this problem by providing needed political support (Meyer, 2015).

So long as the welfare benefits from the environmental aspect of a policy exceed the welfare losses from the protection created by a policy, the kind of Baptist-Bootlegger coalitions that seem to underly the EU's biodiesel policies can be welfare enhancing overall. By contrast, where the international trade regime prevents politicians from using support for environmental programs to reward domestic economic interests, political support for valuable environmental programs may be harder to come by. In situations in which a Baptist-Bootlegger coalition is necessary to the passage of a policy that creates substantial public goods, preventing protectionist policies could actually be welfare decreasing relative to the status quo.

Second, the decision in EU-Biodiesel (Indonesia) permits Indonesia to intervene in its market for purposes of aiding its domestic biofuel industry through a means other than a classic subsidy, but prohibits the EU from doing the same in aid of its promotion of the more environmentally friendly sector of the same industry. Government action that seeks to invest in environmental technologies often requires years of support to develop environmentally sound products that can replace environmentally burdensome products. When this is true, governments may find themselves in the position of supporting environmentally questionable practices, such as biofuels or aquaculture, in the hope that progress in those industries will allow them to become environmentally safe alternatives to unsustainable natural resource consumption (Meyer, 2018).

The EU has followed this path. Its initial support for biofuels included support for vegetablebased biofuels like palm oil-based biodiesel. As the biofuel sector has matured, however, the EU has decided to shift its support to second-generation biofuels. Because they are not based on foodstocks, such biofuels hold out the possibility of the environmental benefits of biofuels (e.g., reduced greenhouse gas emissions) without the attendant costs in the forms of ILUC and distorted food markets.

In this way, the EU is trying to do the same thing as Indonesia and Argentina. The latter have intervened in their economies through their DET systems in order to climb the value-added chain. The EU, as its amendments to the Renewable Energy Directive make clear, is trying to do the same, encouraging the development and use of second-generation biofuels with greater environmental benefits. Indeed, antidumping duties have similar protective effects as a DET system. By suppressing the export of inputs and thereby reducing their price, a DET system encourages the sale of cheap inputs to domestic producers. Antidumping duties (and tariffs more generally), by allowing domestic producers to capture more market share at potentially higher prices, redirects private funds to domestic producers, albeit at the point of sale of the final product rather than during the purchase of inputs.

Further, both the EU's antidumping duties and Indonesia's DET are essentially taxes imposed at the border. The effect of the EU-Biodiesel (Indonesia) decision is thus to allow the effective subsidization of a product through export taxes on key inputs, while not allowing similarly effective protection through import duties designed to counteract the export tax. In the case of biodiesel, the environmental features complicate an assessment of the welfare consequences of these policies. The consumption of biodiesel creates benefits by reducing the use of fossil fuels; in this case, policies that lower prices (like the DET) raise benefits, while policies that raise prices (like the antidumping duties) lower them. On the other hand, the production of the renewable resources used to make the biodiesel entail their own environmental harms, and palm oil production is often relatively more detrimental; in this case, policies that discriminate against palm oil use can generate environmental benefits. The DET actually reduced the return to palm oil production in Indonesia, and the EU duty further discouraged palm oil demand from Indonesian biodiesel producers. 
In the longer term, the environmental benefits from renewable fuels also depend on the development of cleaner, second-generation alternatives. If a strong conventional biodiesel industry is a necessary starting point to develop the R\&D investments and learning-by-doing needed to advance to the next level, initial protection of this industry can in theory further the cause of greater environmental benefits in the future. Without a means to respond, market interventions like the DET system have the potential to undercut the EU's efforts to develop a higher value, and more environmentally friendly, biodiesel industry. For products with limited social value beyond that captured by producers and consumers, this undercutting is unproblematic because the market captures the social value of products. But for products with large social costs or benefits not captured by the market - and in the case of renewable energy, even the market for blending credits may not capture all these social values - it may make sense to prefer complementary government support policies that have the largest social benefits (or smallest social costs).

Three caveats are necessary. First, the DET system itself is a response to the differential tariffs developed countries like the EU have on commodities versus finished goods. By reducing the costs of domestic biodiesel producers to offset the tariffs those producers will face on the export market, Indonesia and other developing countries are - as the EU itself has pointed out (EU, 2016) - merely trying to level the playing field for higher-value goods.

Second, these welfare considerations go beyond what a WTO panel is authorized to consider within the context of an antidumping dispute. As such, these welfare considerations suggest that trade rules more generally may need to change. Because of their relative flexibility, trade remedies have increasingly become the vehicle that governments use to respond to a wide range of distorting behaviors for which trade remedies were not necessarily designed (e.g., Crowley and Hillman, 2018). It is unclear that current trade remedies law can carry that burden.

Third, this argument does not deny that in principle the EU (or other countries seeking to promote environmentally friendly goods) may have other WTO-compatible tools available to them. In particular, larger direct production subsidies for EU producers of second-generation biofuels could offset the effect of the DET system and allow the EU to support both its proverbial Baptists and bootleggers. The difficulty is, again, politics. Subsidies, especially direct financial contributions, are relatively more costly politically precisely because they are transparent. Providing de facto subsidies through various taxes (as both the EU and Indonesia have done), or through regulations may be more politically palatable because they are not transparent. The question is thus often which of two less desirable instruments a government should choose.

\subsection{Instrument Choice}

Turning to the issue of instrument choice, a core tenet in environmental economics is that the policy incentives should address the environmental problem in the most direct manner possible. From this point of view, the primary problem government biofuel policies attempt to solve is greenhouse gas emissions from transportation fuels, with development of the biofuels industry and innovation as secondary goals. The EU's blend mandate was the intended tool for all these goals, but is not necessarily the most direct option. It did not put a price on carbon - either on fossil fuels or the pollution embodied in biofuels; rather, it aimed to displace a given percentage of fossil fuels with biofuels meeting a minimum standard of emissions reductions. Several international organizations (e.g. the International Food Policy Research Institute, IFPRI, and the International Council on Clean Transportation, ICCT) raised concerns about the environmental consequences of foodstock-based biofuels, in part due to ILUC, but the European Biodiesel Board opposed effective emissions taxes, since the industry had an interest in using those sources. Nor was the blend mandate alone sufficient for domestic industrial development, since the target could also be met with imports. Hence, the turn to protection.

The EU has pursued two lines of protection against palm oil-based biodiesel from Indonesia. The first, antidumping duties and now countervailing duties, uses duties to provide protection 
against allegedly subsidized foreign goods. The second, the phasing out of palm oil-based biodiesel under the 2018 Renewable Energy Directive, which lays out stronger standards for the environmental characteristics of eligible biofuels. The question is whether there is reason to prefer one form of protection over another in mixed-motive cases.

Trade scholars have often thought that regulatory protectionism is considerably worse than tariff-based protectionism (Sykes, 1999). In part, this belief stems from the fact that regulatory protectionism is among the least transparent ways to regulate international trade. Duties make explicit the connection between the global price of a good and its price within the protected market. Regulatory protectionism, however, leaves the connection between the global market and the protected market obscure (Dunkel and Roessler, 2016). The deadweight loss associated with regulatory protectionism is thus often greater than that associated with protectionism through duties (Sykes, 1999), This view suggests that when the political demand for protection is relatively inelastic - as it seems to be in the EU with regard to biodiesel - and the importing nation has mixed motives for seeking protection, trade remedies may be a preferable form of protection.

On the other hand, numerous scholars have argued that domestic regulations that pursue non-protectionist objectives should be upheld even if they have the effect of restricting trade (e.g., Sykes, 1999; Pauwelyn, 2005). And the WTO Appellate Body has seemed to follow this advice in at least some cases, such as EC-Asbestos. The argument for upholding domestic regulations that pursue non-protectionist objectives while also restricting trade flows rests essentially on the bargain parties to a trade agreement have struck. While they have agreed to discipline market access restrictions, they have also generally agreed to permit domestic regulations so long as such regulations are not discriminatory (Pauwelyn, 2005). Specific domestic regulations that have adverse trade effects may therefore be more properly the subject of negotiations between countries, rather than the subject of dispute resolution (Sykes, 1999).

The upshot of such reasoning is that domestic regulations that pursue non-protectionist objectives should be upheld more freely than market access restrictions that may also pursue nonprotectionist objectives (along with protectionist ones). Yet the danger of such an approach has long been recognized. ${ }^{38}$ If protection in regulatory form is more easily upheld than via duties, governments will have an incentive to design their protectionist measures as regulations - a move that increases the deadweight loss from protectionism. On the other hand, unless duties are applied to address a legitimate environmental problem, reliance on them is often worse than reasonably designed regulation for environmental protection.

EU-Biodiesel (Indonesia) illustrates exactly these risks and the difficulties of comingling environmental and industrial objectives. The EU initially sought to use duties against Indonesian biodiesel to protect its industry. When that approach was struck down, the EU pivoted in part to a domestic regulation - the 2018 Renewable Energy Directive and its associated phasing out of biofuels with 'high indirect land use change (ILUC) risk' - that disfavors Indonesian biodiesel. The 2018 Renewable Energy Directive has a straightforward environmental explanation and is backed by a scientific assessment of the relatively greater environmental risks posed by palm oil-based biodiesel. At the same time, going forward the measure appears to restrict the market opportunities for Indonesia's palm-oil based biodiesel more than EU rapeseed-based biodiesel or Argentinian soy-based biodiesel.

More generally, EU-Biodiesel (Indonesia) exposes several underappreciated risks of WTO trade remedies jurisprudence. One is the possibility that governments will substitute regulations for duties, decreasing transparency. The second is that this substitution will lead to an increase in WTO challenges to regulatory measures that rest on mixed motives and have both legitimate and

\footnotetext{
${ }^{38}$ E.g., AB Report, European Communities-Measures Affecting Asbestos and Asbestos-Containing Products, WT/DS135/AB/ $\mathrm{R}$ (April 5 2001), para. 99 ('we recognize that the relationship between these two provisions is important, because there is no sharp distinction between fiscal regulation, covered by Article III:2, and non-fiscal regulation, covered by Article III:4. Both forms of regulation can often be used to achieve the same ends').
} 
trade-restricting effects. In other words, WTO panels and the Appellate Body will increasingly have to undertake the difficult and politically fraught task of determining when governments have done enough to suppress the protectionist motives and effects underlying mixed motive regulations. These line-drawing exercises, which often occur doctrinally within the confines of the chapeau of GATT article XX, lead to a jurisprudence that is internally incoherent (Bown and Trachtman, 2009). An institution regularly in the position of applying an internally incoherent jurisprudence to strike down domestic political bargains is an institution sure to face a legitimacy crisis.

Of course, the Appellate Body's legitimacy crisis and its connection to trade remedies jurisprudence is well understood. But the criticism of the trade remedies jurisprudence often rests on either a contractual argument - the Appellate Body has read the covered agreements in ways not agreed to by the contracting parties - or an argument that the jurisprudence leaves states unable to respond to new threats to the trading system (Crowly and Hillman, 2018). Our point is a third. A restrictive trade remedies jurisprudence may decrease economic welfare by pushing demands for protection into regulations and then prompting challenges to the resulting mixed motive regulations. The latter trend serves only to exacerbate the ongoing debate about the WTO's future.

\section{Conclusion}

As a legal dispute, the panel report in EU-Biodiesel (Indonesia) is unexceptional. The panel applied the Appellate Body's earlier decision in EU-Biodiesel (Argentina), a decision that itself gave effect to an ordinary reading of the Antidumping Agreement. As a broader dispute about trade and environmental policy, however, EU-Biodiesel (Indonesia) is an significant site for conflict over trade law's relationship to other policy domains. As current events attest, the WTO's ability to reduce the demand for protection is modest at best. Restrictive trade remedies laws thus may do little to boost economic welfare through reduced trade barriers. Instead, restrictive trade remedies laws may either chill industry's appetite for addressing difficult social challenges or otherwise allow market distortions that are beyond the scope of WTO law to flourish and may lead to a rise in regulatory protection.

These effects are not inevitable. They are, however, a consequence of the fact that modern trade law was not designed to take into account a wide range of considerations - ranging from environmental issues to human rights and domestic economic development - that are forefront in modern goverance. While environmental issues are not central to the WTO's current crisis, rethinking how the WTO deals with environmental issues would go a long way toward defusing future conflicts.

\section{References}

Aisyah R (2019) Private Sector to Challenge EU Biofuel Ban. Jakarta Post, 15 June 2019.

Bown CP and Trachtman JP (2009) Brazil - Measures Affecting Imports of Retreaded Tyres: A Balancing Act. World Trade Review 8(1), 85-135.

Charnovitz S and Fischer C (2015) Canada - Renewable Energy: Implications for WTO Law on Green and Not-So-Green Subsidies. World Trade Review 14(2), 177-210.

Christina B (2019) Indonesia Says EU Anti-Subsidy Duty Part of Plan to Block Palm Oil. Reuters, 13 August 2019.

Coglianese C and Sapir A (2017) Risk and Regulatory Calibration: WTO Compliance Review of the US Dolphin-Safe Tuna Labeling Regime. World Trade Review, 16(2), 327-348.

Crowley MA and Hillman JA (2018) Slamming the Door on Trade Policy Discretion? The WTO Appellate Body's Ruling on Market Distortions and Production Costs in EU-Biodiesel (Argentina). World Trade Review 17(2), 195-213.

DeSombre ER (1995) Baptists and Bootleggers for the Environment: The Origins of United States Unilateral Sanctions. Journal of Environment and Development 4(1), 53-75.

Dunkel A and Roessler F (2016) The Ranking of Trade Policy Instruments under the GATT Legal System. In Pauwelyn, Guzman, and Hillman (eds.) International Trade Law, pp. 224-228. 
European Union (EU) (2016) Export Taxes and Other Restrictions on Raw Materials and Their Limitation through Free Trade Agreements: Impact on Developing Countries. Study of the European Parliament, Directorate-General for External Policies, Policy Department. EP/EXPO/B/DEVE/FWC/2013-08/LOT7/15.

Fargione J, Hill J, Tilman D, Polasky S, and Hawthorne P (2008) Land Clearing and the Biofuel Carbon Debt. Science 319, 1236-1238.

Hamelinck C et al. (2012) Renewable Energy Progress and Biofuels Sustainability: Report for the European Commission, https://hub.globalccsinstitute.com/publications/renewable-energy-progress-and-biofuels-sustainability/renewable-energyprogress-and-biofuels-sustainability.

Howse R and Neven DJ (2003) US-Shrimping: United States: Import Prohibition of Certain Shrimp and Shrimp Products, Recourse to Article 21.5 of the DSU by Malaysia. The WTO Case Law of 2001: The American Law Institute Reporters' Studies, 41-71.

International Council on Clean Transportation (2019) International Policy and Market Drivers of Indonesian Palm Oil Demand, www.theicct.org/sites/default/files/publications/Palm_Oil_Briefing_20190130_0.pdf.

IRENA (2017) Renewable Energy Prospects: Indonesia. International Renewable Energy Agency (March 2017).

Kellow A (1999) Baptists and Bootleggers? The Basel Convention and Metals Recycling Trade. Agenda 6(1), 29-38.

Meyer T (2015) How Local Discrimination Can Promote Global Public Goods. Boston University Law Review 95(6), $1937-2025$.

Meyer T (2018) Free Trade, Fair Trade, and Selective Enforcement. Columbia Law Review 118(2), 491-566.

Pauwelyn J (2005) Rien ne Va Plus? Distinguishing Domestic Regulation from Market Access in GATT and GATS. World Trade Review 4(2), 131-170.

Rifin A (2014) The Effect of Progressive Export Tax on Indonesian Palm Oil Industry. Oil Palm Industry Economic Journal 14(1), 1-8.

Solomon BD (2010) Biofuels and Sustainability. Annals of the New York Academcy of Sciences 1185, 119-134.

Sykes AO (1999) Regulatory Protectionism and the Law of International Trade. University of Chicago Law Review 66(1), 1-46.

United States Department of Agriculture (USDA) (2010) Biofuels Annuals, Jakarta (Indonesia).

USDA (2018) Biofuels Annuals, Jakarta (Indonesia).

Wicke B et al. (2011) Exploring Land Use Changes and the Role of Palm Oil Production in Indonesia and Malaysia. Land Use Policy 28, 193-206.

Yandle B (1983) Bootleggers and Baptists: The Education of Regulatory Economist. Regulation 7, $12-16$.

Yandle B and Buck S (2002) Bootleggers, Baptists, and the Global Warming Battle. Harvard Environmental Law Review 26, 177-229.

Cite this article: Fischer C, Meyer T (2020). Baptists and Bootleggers in the Biodiesel Trade: EU-Biodiesel (Indonesia). World Trade Review 19, 297-315. https://doi.org/10.1017/S1474745620000075 